\title{
Droplet digital PCR quantification suggests that higher viral load correlates with improved survival in HPV-positive oropharyngeal tumours
}

\author{
A. Stevenson ${ }^{\mathrm{a}}$, K. Wakeham ${ }^{\mathrm{b}}$, J. Pan $^{\mathrm{c}}, \mathrm{K} \cdot$ Kavanagh $^{\mathrm{c}}$, D. Millan ${ }^{\mathrm{e}}, \mathrm{S}$. Bell $^{\mathrm{e}}$, D. McLellan $^{\mathrm{e}}$, \\ S.V. Graham ${ }^{\text {a }}$, K. Cuschieri ${ }^{\mathrm{d}, *}$ \\ ${ }^{a}$ Centre for Virus Research, Institute of Infection Immunity and Inflammation, College of Medical Veterinary and Life Sciences, University of Glasgow, Glasgow, UK \\ ${ }^{\mathrm{b}}$ Sussex Cancer Centre, Brighton, UK \\ ${ }^{\mathrm{c}}$ Department of Mathematics and Statistics, University of Strathclyde, Glasgow, UK \\ ${ }^{\mathrm{d}}$ Scottish HPV Reference Laboratory, Royal Infirmary of Edinburgh, 51 Little France Crescent, Edinburgh, UK \\ ${ }^{\mathrm{e}}$ Department of Pathology, The Queen Elizabeth University Hospital, NHS Greater Glasgow and Clyde, Glasgow, UK
}

\section{A R T I C L E I N F O}

\section{Keywords:}

Oropharyngeal cancer

HPV

Viral load

Droplet digital PCR

\begin{abstract}
A B S T R A C T
Background: Although HPV-positive oropharyngeal cancer (OPC) patients have improved prognosis compared to HPV negative patients; there remains an HPV-positive group who have poor outcomes. Biomarkers to stratify discrete patient outcomes are thus desirable. Our objective was to analyse viral load (VL) by droplet digital PCR (ddPCR), in HPV-positive patients with OPC on whom clinical outcome data were available.

Methods: In a cohort of patients that had previously tested HPV positive via conventional PCR, VL was determined using ddPCR assays for HPV16 L1 and E6 genes. VL was classed as "medium/high" if more than 5.57 copies or 8.68 copies of the HPV 16 L1 or E6 gene were detected respectively. Effect of VL on overall survival and hazard of death \& disease progression was performed with adjustments made for sex, age, deprivation, smoking, alcohol consumption and stage.

Results: L1 VL ranged from 0.0014-304 gene copies per cell with a mean of 30.9; comparatively E6 VL ranged from 0.0012-356 copies per cell with a mean of 37.9. Univariate analysis showed those with a medium/high VL had a lower hazard of death; this was significant for L1 $(p=0.02)$ but not for E6 $(p=0.67)$. The ratio of E6 to L1 deviated from $\mathrm{n}=1$ in most samples but had no influence on clinical outcomes.

Conclusions: HPV viral load may be informative for the further stratification of clinical outcomes in HPV positive OPC patients
\end{abstract}

\section{Introduction}

The incidence of oropharyngeal cancer (OPC) has increased dramatically over the last two decades including in the United Kingdom $[1,2]$. A component of OPC is associated with HPV although the amount varies. For example, a recent global analysis indicated $<10 \%$ of OPC cases in Brazil were positive for HPV compared to $~ 50 \%$ in the UK [3]. While the extent of HPV driven OPC varies, data converge on the fact that HPV positive (versus negative) status is independently associated with better clinical outcomes $[4,5]$. This has led to a recent change in tumour classification which incorporates HPV status and also trials to determine the efficacy of de-escalated therapy in HPV positive OPC patients $[6,7]$.

Current approaches for determining HPV status of OPC are largely based on qualitative tests and include immunohistochemistry for
p16INK4a or HPV PCR for DNA or mRNA [8]. Unfortunately, some HPV-positive patients, so determined by these methods, still have very poor outcomes [9]. Further, these approaches do not quantify levels of infection i.e. viral load (VL). Given the increased incidence of OPC, it is important to refine tools for improved risk stratification; one such candidate is the measurement of viral load.

Current evidence indicates that VL in HPV-positive head and neck cancers varies widely within and between anatomical sites [10-14]. In addition, investigations into the physical status of HPV in OPC indicate a landscape of integrated and episomal forms within a single lesion $[15,16]$. The implications of physical status on clinical outcome are not understood but given the fundamental influence of integration on viral gene expression, a simple measure of virus activity (such as VL in the lesion) may yield insight into clinical manifestations.

To date, small cohort studies have indicated VL measurement can

\footnotetext{
* Corresponding author.

E-mail address: Kate.Cuschieri@nhslothian.scot.nhs.uk (K. Cuschieri).
} 
delineate patient outcomes within HPV positive OPC [17]. This reconciles with data that indicate VL may be prognostic for other HPV driven cancers, including cervix $[18,19]$. Previous studies on VL have generally focussed on the amplification of one target and have employed real-time PCR. ddPCR allows absolute quantification of DNA targets and has been used for applied virology where knowledge of load can influence clinical management $[20,21]$. Around 20,000 data points are generated per sample making it highly accurate and reproducible (2021) and proof principle of this approach when applied to OPC for single HPV target-detection was reported recently [22]. The present study builds on this work through the evaluation of a ddPCR approach to measure VL of two HPV gene targets: E6 and L1, within a well characterised cohort of OPC cases diagnosed in Scotland on which clinical and survival outcomes are known. Our overarching aim is to determine the utility of HPV viral load measurement for the risk-stratification of OPC

\section{Methods}

\subsection{Dimensions of original, parent OPC cohort}

We focussed on a subsample of an OPC cohort from Scotland $(n=235)$. Full details of the original cohort are available in Wakeham et al. 2019 [23]. In brief, patients with OPC diagnosed in the West of Scotland between April 2013 and December 2015 had PCR-based HPV typing, performed in a central reference laboratory in Scotland. The original PCR-based assay targeted L1 DNA and incorporated genotyping using luminex technology for $24 \mathrm{HPV}$ types including all established high-risk HPV types. HPV positivity using this technology is associated with improved clinical outcomes; as described in Wakeham et al. (2019) and concordance of the assay with p16INK4a staining is between $80-90 \%$ [2]. Of the technically valid cases $(n=229), 136$ were HPV positive and 130/136 were positive for HPV 16.

\subsection{Sample(s) used for VL analysis}

An aliquot of the original nucleic acid extraction stored at $-80^{\circ} \mathrm{C}$, was obtained. Given the dominance of HPV 16 in OPC generally, including the present cohort, HPV 16-specific ddPCR protocols were generated. 113 HPV 16 positive samples were available for the ddPCR after exclusion for limiting volume or incomplete clinical data. Of these, 93 and 82 tested positive for L1 and E6 respectively and were the focus of subsequent analysis. Sex, age, deprivation (represented as quintiles; $1=$ most deprived, 5 least deprived), smoking (ever/never), alcohol consumption (heavy vs not), TMN stage, ICON-S stage and treatmenttype were recorded as per Wakeham et al. 2019 [23]. Study permissions were through NHS Greater Glasgow and Clyde research office, the clinical effectiveness team and a data sharing agreement with the West of Scotland Cancer network.

\section{3. ddPCR methodology and optimisation}

ddPCR was carried out to conform to the MIQE guidelines for ddPCR [24,25]. Copy number variant (CNV) analysis was used to determine average HPV16 VL/cell. ddPCR assays were set up as duplexes with the cellular RPP30 control probe primer set, supplied as standard for ddPCR (BioRad, UK), and either custom-designed HPV16 L1-specific primers and probe sets (HPV16 L1 Forward Primer 5'-GCCTCCTGTCC CAGTATCTAA-3', HPV16L1 Reverse Primer 5'-GGATGTCCAACTGCAA GTAGTC-3', HPV16L1 Probe 5'-TGCGTGCAACATATTCATCCGTGC-3') [26] or HPV16 E6-specific primers and probe sets (E6 Forward Primer 5'-CAATGTTTCAGGACCCACAG-3', E6 Reverse Primer 5'-CTGTTGCTT GCAGTACACACATTC-3', E6 Probe 5'-CCACAGTTATGCACAGAGC TGC-3') [27]. For L1 and E6 probes the reporter dye was FAM and the dark quencher was BHQ1 (IDT, Belgium). Primers and probes were designed using IDT's Primer Quest Tool (https://eu.idtdna.com/
PrimerQuest/Home/Index). The probe/primer sets were optimised using a temperature gradient exactly as recommended in the Bio-Rad ddPCR manual. The endogenous control assay kit; Human RPP30 (reporter dye HEX) (Bio-Rad, UK) was included in every ddPCR reaction as a copy number reference, i.e. each ddPCR was a duplex reaction. All reaction runs contained negative control wells in triplicate. In-reaction digestion of the DNA with restriction enzymes was performed to enhance the partitioning of DNA into droplets. We confirmed that the restriction enzymes selected for this (EcoRI and HindIII), would not cut within any of the viral or control target sequences. Primer and probe concentrations were optimised by titration. Reaction mixes were set up using ddPCR Supermix for Probes without dUTP (Bio-Rad), $0.7 \mu \mathrm{L}$ of the RPP30 endogenous control assay, HPV16 L1 or E6 specific primers and probes at $300 \mathrm{nM}$ and $200 \mathrm{nM}$ (final concentration) respectively, $10-100 \mathrm{ng}$ of template DNA and $1 \mu \mathrm{L}$ of restriction digest mix (consisting of $4 \mathrm{U}$ of both EcoRI and HindIII in 1x NEB Cutsmart buffer (NEB, UK)). Reactions were mixed with Droplet Generation Oil on DG8 cartridges in the QX200 droplet generator (Bio-Rad) to generate droplets. Thermal cycling conditions were: $95^{\circ} \mathrm{C}$ for $10 \mathrm{~min}$ followed by $40 \times 94{ }^{\circ} \mathrm{C}$ for $30 \mathrm{~s}$ and $60^{\circ} \mathrm{C}$ for $1 \mathrm{~min}$ prior to final extension at $98^{\circ} \mathrm{C}$ for $10 \mathrm{~min}$. Post amplification, droplets were analysed on a QX200 Droplet Reader (Bio-Rad) and output data files were analysed using QuantaSoft analysis software v1.7.4 (Bio-Rad).

\subsection{Definition of low and high VL}

The individual viral loads were ranked from smallest to largest and separated using tertiles. A priori, the analysis planned to compare viral load in tertiles (low, medium and high) but low numbers of deaths in the medium and high viral load groups meant that analysis was performed for low VL(viral load in the lowest third) vs a combined medium/high VL category (viral load in the upper two-thirds); this was performed for both L1 and E6. The VL threshold(s) for "medium/high" E6 VL and L1 VL were $>8.68$ and $>5.57$ viral gene copies per cell respectively. Samples with VL lower than this were classed as having a low VL.

\subsection{E6 and L1 VL and clinical outcome}

Analysis was performed on the cases which had ddPCR results ( $n=93$ for L1 and $n=82$ for E6). Kaplan Meier plots were constructed for overall and progression free survival, stratified according to the OPC cases having a low or medium/high VL. In addition, hazard to death and hazard to death or recurrence were assessed and related to low or medium/high VL status using Cox's regression with Firth's penalised likelihood given the small denominators. Follow up data were censored as of November 2016. Univariate and adjusted results are presented with adjustments made for sex, age, deprivation, smoking, alcohol intake, TMN stage, ICON stage. Type of treatment was not included in the model given its high association with stage.

\subsection{Ratios of E6 and L1 VL and clinical outcome}

The association(s) between E6/L1 ratio and the demographic and clinical variables were assessed with significance determined using the Fishers exact test. Further, we modelled the association between the distance of the E6/L1 ratio to 1 and the variables using a regression model (to avoid imposing an "arbitrary" cut off). As the effect may have been different for E6/L1 $>1$ vs $<1$, tests for interaction were performed to determine whether they could be included with the same model. All statistical analyses were performed in $\mathrm{R}$ version 3.6.1. 
Table 1

Table 1: Demographic \& clinical characteristics of the study cohort, including L1 and E6 viral load.

\begin{tabular}{|c|c|c|}
\hline Variable & Level & n $(\%)($ Total $=93)$ \\
\hline \multirow[t]{2}{*}{ Sex } & Female & $18(19.4)$ \\
\hline & Male & $75(80.6)$ \\
\hline \multirow[t]{5}{*}{ Age } & $<50$ & $14(15.1)$ \\
\hline & $50-59$ & $42(45.2)$ \\
\hline & $60-69$ & $20(21.5)$ \\
\hline & 70 and over & $17(18.3)$ \\
\hline & median (IQR) & $57(52-66)$ \\
\hline \multirow[t]{6}{*}{ SIMD } & 1: most deprived & $29(31.2)$ \\
\hline & 2 & $21(22.6)$ \\
\hline & 3 & 12(12.9) \\
\hline & 4 & $15(16.1)$ \\
\hline & 5: least deprived & $15(16.1)$ \\
\hline & Missing & $1(1.1)$ \\
\hline \multirow[t]{3}{*}{ Smoking status } & No & $38(40.9)$ \\
\hline & Yes & $53(57)$ \\
\hline & Missing & $2(2.2)$ \\
\hline \multirow[t]{3}{*}{ Alcohol status } & No & $69(74.2)$ \\
\hline & Yes & $19(20.4)$ \\
\hline & Missing & $5(5.4)$ \\
\hline \multirow[t]{6}{*}{ TMN stage } & 1 & $2(2.2)$ \\
\hline & 2 & $7(7.5)$ \\
\hline & 3 & $10(10.8)$ \\
\hline & $4 a$ & $69(74.2)$ \\
\hline & $4 \mathrm{~b}$ & $4(4.3)$ \\
\hline & $4 c$ & $1(1.1)$ \\
\hline \multirow[t]{4}{*}{ ICON stage } & 1 & $13(14)$ \\
\hline & 2 & $54(58.1)$ \\
\hline & 3 & $25(26.9)$ \\
\hline & 4 & $1(1.1)$ \\
\hline \multirow[t]{6}{*}{ Treatment } & RT & $15(16.1)$ \\
\hline & BSC & $5(5.4)$ \\
\hline & CRT & $56(60.2)$ \\
\hline & SCRT & $12(12.9)$ \\
\hline & SRT & $4(4.3)$ \\
\hline & surgery & $1(1.1)$ \\
\hline \multirow[t]{3}{*}{ L1 viral load } & low $(<=5.57)$ & $31(33.3)$ \\
\hline & medium $(5.57,25.63]$ & $31(33.3)$ \\
\hline & high $(>25.63)$ & $31(33.3)$ \\
\hline \multirow[t]{4}{*}{ E6 viral load } & low $(<=8.68)$ & $28(30.1)$ \\
\hline & medium $(8.68,28.51]$ & $27(29)$ \\
\hline & high $(>28.51)$ & $27(29)$ \\
\hline & missing & $11(11.8)$ \\
\hline
\end{tabular}

\section{Results}

\subsection{Characteristics of cohort assessed for VL}

Demographic and clinical variables of the cohort are presented in Table 1 in addition to VL status separated as "low", "medium" or "high". The cohort contained 75 males and 18 females with an average age of 57 (interquartile range of 52-66). All were squamous cell carcinomas and most cases were from more deprived areas; 50/93 patients were SIMD 1 and 2. In relation to smoking and alcohol, 53 had "ever" smoked and 19 were heavy drinkers. A total of 84 cases were TMN 3 or above and most, (56/93), received chemo-radiotherapy as treatment.

\subsection{VL and impact on clinical outcomes (L1)}

All original data files for this study have been uploaded to the University of Glasgow's open access data sharing platform "Enlighten" (http://researchdata.gla.ac.uk/) The DOI for accession to this data is https://doi.org/10.5525/gla.researchdata.1023

Samples were analysed singly and any assay generating less than 10,000 droplets was discounted from analysis. Raw data for the average HPV16 VL per cell as deduced from ddPCR experiments are presented in Supplementary Table 3. This shows the VL (based on either the L1 or E6 DNA targets) calculated relative to the endogenous RRP30 cellular gene internal control, which is known to have two copies per cell. A threshold is set on the QuantaSoft analysis software (either automatically or manually as required http://www.bio-rad.com/webroot/ web/pdf/lsr/literature/Bulletin_6407.pdf) and from this, the number of positive and negative droplets for both gene targets in each patient sample is measured. The software then fits the positive droplets to a Poisson algorithm to determine the target DNA concentrations. L1 VL ranged from 0.0011-304 copies of HPV L1 gene per cell with a mean of 30.9 L1 copies. Those who died from OPC had a median L1 VL of 5.21 (IQR 0.23-18.15); while those still alive had a median L1 VL of 16.3 (IQR 4.13-33.65). Table 2 shows overall survival stratified by the clinical and demographic variables described in Table 1 in addition to viral load defined as medium/high (treated as a composite) or low. Medium/high viral load was associated with improved overall survival in the univariate analysis with a hazard ratio of 0.3 (95\% CI $0.11-0.84), p=0.02$. Variables associated with a worse overall survival were high alcohol consumption; HR 4.94 (95 \% CI 1.7-14.39) $\mathrm{p}<0.01$, more advanced stage and treatment modality. Similar observations were noted when progression free survival was used as an outcome (Supplementary data 1). Fig. 1 shows overall survival and progression free survival according to the binary VL categories.

In the adjusted analysis no individual variable, including viral load, influenced overall survival other than high alcohol consumption; HR 3.6 (95 \% CI 0.98-15.22) - although the confidence interval spanned 1. Alcohol consumption was also associated with a significantly worse progression free survival; HR 5.48 (95 \% CI 1.56-19.22) in the adjusted analysis (supplementary Table 1 ).

\subsection{VL and impact on clinical outcomes (E6)}

E6 VL ranged from 0.0012-356 copies of HPV E6 gene per cell. Mean viral load was 37.9 E6 gene copies per cell and those who died from OPC had a E6 VL of 12.19 (IQR 6.65-39.25), while those still alive had a median E6 VL of 15.69 (IQR 6.04-41.81).

Medium/high viral load was weakly associated with longer overall survival and progression free survival although the relationship was not as strong as that observed for L1 (Fig. 2). In the univariate analyses, medium/high E6 VL was associated with a slightly higher overall survival although this was not significant; HR 0.76 (95 \%CI $0.21-2.68$ ) $\mathrm{p}=0.67$ (Table 3, Fig. 2). High alcohol intake was associated with worse overall survival; HR $4.31(95 \% \mathrm{CI} 1.18-15.67) \mathrm{p}=0.03$, as was treatment type. These observations were unchanged when progression free survival was assessed (Supplementary Table 2).

\section{4. $L 1$ v s E6 ratio}

All viral genes in an HPV genome have an expected copy number of one. Comparison of VL measured by L1 versus E6 gene copy number revealed a small deviance from "copy $=$ one" in almost all cases. However, in 19 cases out of 82 positive for E6, there was almost a one log range of values (0.262-2.27 copies of E6/L1) (Fig. 3). We modelled the distance of E6/L1 to 1 against demographic and clinical variables; none of the demographic or clinical variables were significantly associated with the distance of E6/L1 to 1 .

\section{Discussion}

We have demonstrated that ddPCR is an accurate and rapid method for determining HPV VL in OPC patients, consistent with previous studies in smaller cohorts [28,29]. The VL detected with both E6 and L1 genes displayed a wide range but was much more restricted than the $10^{3}$ to $10^{7}$ range reported for 48 OPC patients [12] or 1- > 900 copies in 45 clinical samples, [29], which both detected L1 gene copy numbers.

The ddPCR analysis indicated that a higher L1 VL was associated with better clinical outcomes. One explanation is that cancers with a 


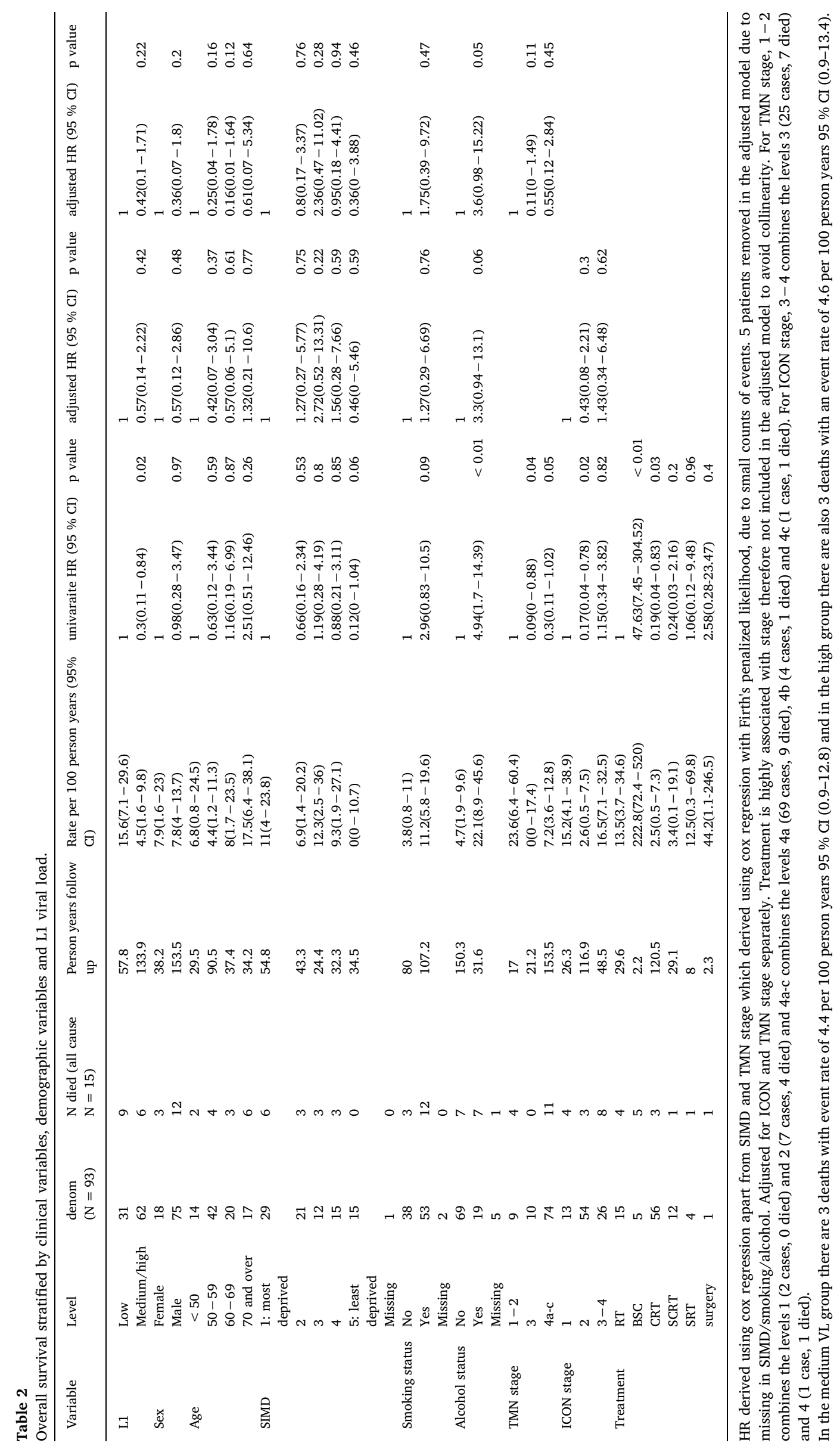


Table 3

Overall survival stratified by clinical variables,demographic variables and E6 viral load. HR derived using cox regression apart from SIMD and treatment which derived using cox regression with Firth's penalized likelihood, due to small counts of events. 4 patients were removed in the adjusted model due to missing in SIMD/ smoking/alcohol. Adjusted for ICON and TMN stage separately. For TMN stage, 1-3 combines the levels 1 ( 2 cases, 0 died),2 ( 3 cases, 1 died) and 3 (10 cases, 0 died) and $4 \mathrm{a}-\mathrm{c}$ combines the levels $4 \mathrm{a}$ (62 cases, 7 died), $4 \mathrm{~b}$ ( 4 cases, 1 died) and $4 \mathrm{c}$ ( 1 case, 1 died). For ICON stage, 3-4 combines the levels 3 ( 21 cases,5 died) and 4 ( 1 case, 1 died).

\begin{tabular}{|c|c|c|c|c|c|c|c|c|c|c|c|}
\hline Variable & Level & $\begin{array}{l}\text { denom } \\
(\mathrm{N}=82)\end{array}$ & $\begin{array}{l}\mathrm{N} \text { died } \\
\text { (all } \\
\text { cause, } \\
\mathrm{N}=10 \text { ) }\end{array}$ & $\begin{array}{l}\text { Person } \\
\text { years } \\
\text { follow } \\
\text { up }\end{array}$ & $\begin{array}{l}\text { Rate per } 100 \text { person } \\
\text { years }(95 \% \mathrm{CI})\end{array}$ & $\begin{array}{l}\text { univariate HR (95 } \\
\% \mathrm{CI} \text { ) }\end{array}$ & $\mathrm{p}$ value & adjusted HR (95 \% CI) & $\mathrm{p}$ value & adjusted HR (95 \% CI) & $\mathrm{p}$ value \\
\hline \multirow[t]{2}{*}{ E6 } & Low & 28 & 4 & 58.3 & $6.9(1.9-17.6)$ & 1 & & 1 & & 1 & \\
\hline & $\begin{array}{l}\text { Medium/ } \\
\text { high }\end{array}$ & 54 & 6 & 115.6 & $5.2(1.9-11.3)$ & $0.76(0.21-2.68)$ & 0.67 & $0.5(0.06-2.54)$ & 0.42 & $0.26(0.02-1.71)$ & 0.17 \\
\hline \multirow[t]{2}{*}{ Sex } & Female & 16 & 3 & 34.3 & $8.7(1.8-25.5)$ & 1 & & 1 & & 1 & \\
\hline & Male & 66 & 7 & 139.6 & $5(2-10.3)$ & $0.57(0.15-2.21)$ & 0.42 & $0.33(0.03-2.15)$ & 0.25 & $0.32(0.03-2.09)$ & 0.24 \\
\hline \multirow[t]{4}{*}{ Age } & $<50$ & 14 & 2 & 29.5 & $6.8(0.8-24.5)$ & 1 & & 1 & & 1 & \\
\hline & $50-59$ & 41 & 3 & 89.2 & $3.4(0.7-9.8)$ & $0.47(0.08-2.82)$ & 0.41 & $0.24(0.02-2.18)$ & 0.2 & $0.11(0.01-1.13)$ & 0.06 \\
\hline & $60-69$ & 15 & 2 & 29.2 & $6.9(0.8-24.8)$ & $0.93(0.13-6.65)$ & 0.94 & $0.93(0.06-11.59)$ & 0.96 & $0.38(0.03-3.75)$ & 0.41 \\
\hline & $\begin{array}{l}70 \text { and } \\
\text { over }\end{array}$ & 12 & 3 & 26 & $11.6(2.4-33.8)$ & $1.66(0.28-9.94)$ & 0.58 & $2.5(0.32-27.36)$ & 0.38 & $2.91(0.33-53.99)$ & 0.35 \\
\hline \multirow[t]{6}{*}{ SIMD } & $\begin{array}{l}1: \text { most } \\
\text { deprived }\end{array}$ & 23 & 3 & 46.5 & $6.4(1.3-18.8)$ & 1 & & 1 & & 1 & \\
\hline & 2 & 18 & 2 & 37.1 & $5.4(0.7-19.5)$ & $0.9(0.15-4.64)$ & 0.9 & $0.96(0.13-5.48)$ & 0.96 & $0.95(0.12-6.59)$ & 0.96 \\
\hline & 3 & 11 & 3 & 22.5 & $13.3(2.7-38.9)$ & $2.01(0.42-9.47)$ & 0.36 & $4.49(0.65-44.58)$ & 0.13 & $6.07(0.65-95.37)$ & 0.12 \\
\hline & 4 & 14 & 2 & 30.9 & $6.5(0.8-23.4)$ & $1.06(0.18-5.47)$ & 0.94 & $1.96(0.23-19.18)$ & 0.53 & $3.36(0.45-28.64)$ & 0.22 \\
\hline & $\begin{array}{l}\text { 5: least } \\
\text { deprived }\end{array}$ & 15 & 0 & 34.5 & $0(0-10.7)$ & $0.2(0-2.04)$ & 0.2 & $0.65(0-10.78)$ & 0.79 & $0.7(0-11.51)$ & 0.82 \\
\hline & Missing & 1 & 0 & & & & & & & & \\
\hline \multirow{3}{*}{$\begin{array}{l}\text { Smoking } \\
\text { status }\end{array}$} & No & 36 & 2 & 77.5 & $2.6(0.3-9.3)$ & 1 & & 1 & & 1 & \\
\hline & Yes & 44 & 8 & 91.8 & $8.7(3.8-17.2)$ & $3.43(0.73-16.16)$ & 0.12 & $4.38(0.6-116.75)$ & 0.17 & $7.69(0.8-246.96)$ & 0.08 \\
\hline & Missing & 2 & 0 & & & & & & & & \\
\hline \multirow{3}{*}{$\begin{array}{l}\text { Alcohol } \\
\text { status }\end{array}$} & No & 65 & 6 & 142.2 & $4.2(1.5-9.2)$ & 1 & & 1 & & 1 & \\
\hline & Yes & 13 & 4 & 22 & $18.2(5-46.6)$ & $4.31(1.18-15.67)$ & 0.03 & $4.1(0.6-41.13)$ & 0.15 & $7.52(0.93-84.18)$ & 0.06 \\
\hline & Missing & 4 & 0 & & & & & & & & \\
\hline \multirow{2}{*}{$\begin{array}{l}\text { TMN } \\
\text { stage }\end{array}$} & $1-3$ & 15 & 1 & 31.5 & $3.2(0.1-17.7)$ & 1 & & & & 1 & \\
\hline & $4 a-c$ & 67 & 9 & 142.4 & $6.3(2.9-12)$ & $2.06(0.26-16.23)$ & 0.49 & & & $5.22(0.62-135.55)$ & 0.15 \\
\hline \multirow{3}{*}{$\begin{array}{l}\text { ICON } \\
\text { stage }\end{array}$} & 1 & 9 & 1 & 19.7 & $5.1(0.1-28.2)$ & 1 & & 1 & & & \\
\hline & 2 & 51 & 3 & 111 & $2.7(0.6-7.9)$ & $0.52(0.05-4.99)$ & 0.57 & $0.96(0.11-16.37)$ & 0.98 & & \\
\hline & $3-4$ & 22 & 6 & 43.1 & $13.9(5.1-30.3)$ & $2.79(0.34-23.21)$ & 0.34 & $3.24(0.43-67.01)$ & 0.31 & & \\
\hline \multirow[t]{5}{*}{ Treatment } & RT & 12 & 3 & 23.8 & $12.6(2.6-36.8)$ & 1 & & & & & \\
\hline & BSC & 3 & 3 & 1.8 & $169.2(34.9-494.6)$ & $25.07(4.09-188.2)$ & $<0.01$ & & & & \\
\hline & CRT & 54 & 3 & 116.6 & $2.6(0.5-7.5)$ & $0.2(0.04-0.96)$ & 0.05 & & & & \\
\hline & SCRT & 10 & 0 & 25.8 & $0(0-14.3)$ & $0.13(0-1.35)$ & 0.09 & & & & \\
\hline & SRT & 3 & 1 & 5.8 & $17.1(0.4-95.3)$ & $1.97(0.19-12.14)$ & 0.51 & & & & \\
\hline
\end{tabular}

In the medium VL group there are 3 deaths with an event rate of 5.3 per 100 person years $95 \%$ CI (1.1-15.4) and in the high group there are also 3 deaths with an event rate of 5.1 per 100 person years $95 \%$ CI (1.1-14.9).

higher VL are virus "driven" - whereas those with lower VLs may represent cancers where other drivers are responsible for the cancer due to impairment of viral function through integration and/or epigenetic mechanisms. Notably, we detected very low levels indeed of L1 with some as low as 0.001 copies per cell. Although such samples tested positive for HPV16 in the original HPV PCR/genotyping test, we accept that the presence of the virus might not drive tumorigenesis in these cases and that some tumours in the "low VL" group could be treated as functionally HPV-negative. We did not test cancers for p16INK4a or E6 RT-PCR or perform in-situ hybridisation for E6/E7 sequences, which can indicate transcriptional activity of virus. This would be of interest for future work and could better clarify the relevance and activity of the virus of the "low VL" group [[30]].

It is known that the mutational burden of HPV-positive OPC is lower than HPV negative cancer; making it amenable to non-surgical treatment options [7]. This may be because the majority of OPCs retain viral episomes and there is a lack of insertional mutagenesis of cellular genes due to integration [31]. Therefore, the association of a higher VL with better outcome could be that multiple viral episomes might allow full virus gene expression, particularly of the highly immunogenic L1 protein. Theoretically, this would allow for greater antigen presentation and immune checks, particularly in the tonsils, which are lymphoid tissue.

HPV genome status in OPC tumours can be episomal or integrated or exist as virus-human episomes or integrants [[32]. While the relationship between integration status and clinical outcome is not fully understood, only low copy numbers have been detected in cases with integrated HPV genomes [32]. Our samples had a mean viral load of 30.9 (L1) or 37.9 (E6), and VL with L1 detection was similar to VL with E6 detection, suggesting the majority of samples had mostly episomal genomes, but this requires confirmation. A surprising finding was that in the majority of samples, the ratio of E6 to L1 was not equal to one and some had greater numbers of E6 vs L1 copies; this may be explained by amplification of E6/E7 genes either in episomal or integrated viral genomes due to recombination events. Conversely, the samples which had more L1 than E6 copies may reflect the presence of full-length genomes alongside partially deleted viral genomes missing the E6 gene. We could not demonstrate a relationship between L1:E6 ratios and clinical/demographic variables or outcomes, but this may be an artefact of the small number of cases. Viral activity in OPCs, including level of HPV gene expression is likely to provide further insight on clinical outcomes. While sequencing is required to address this question, our 
L1 virus load
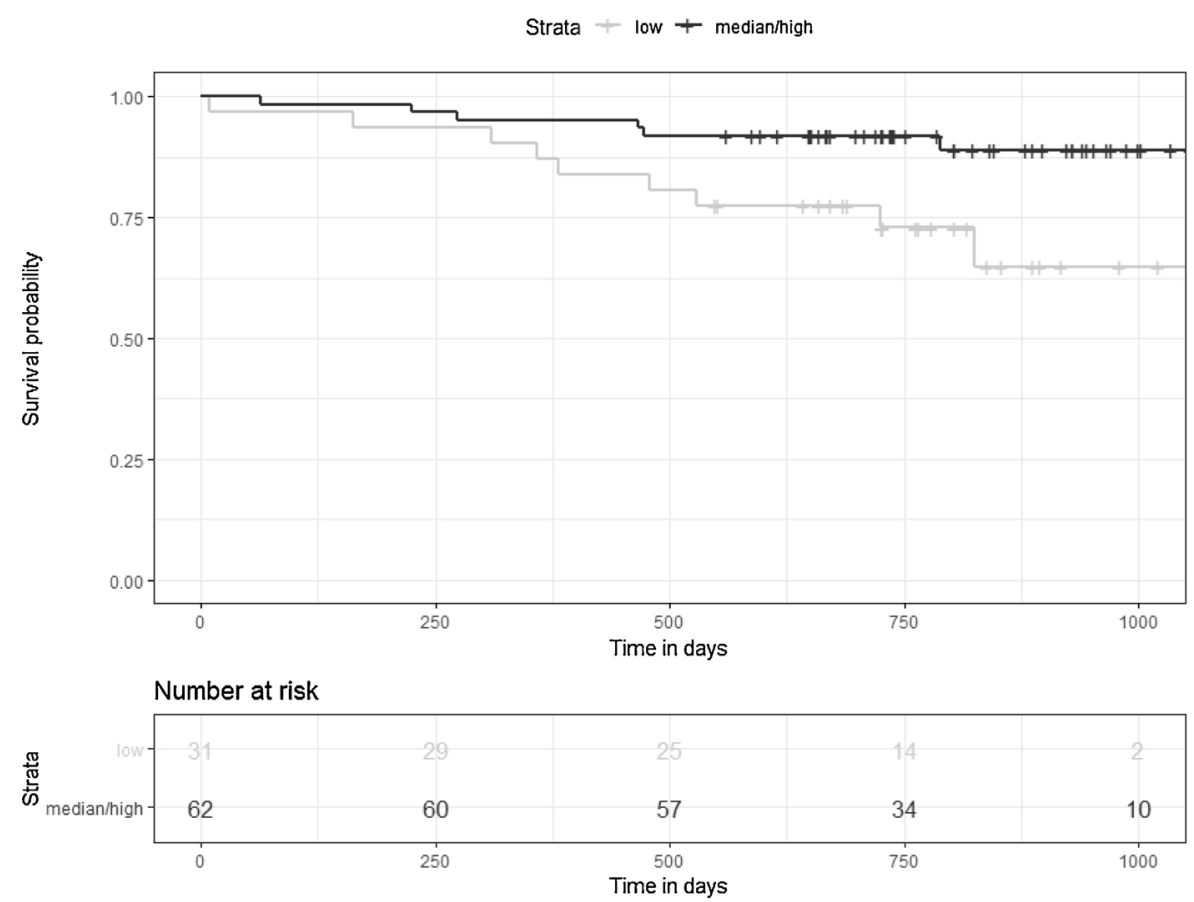

L1 virus load
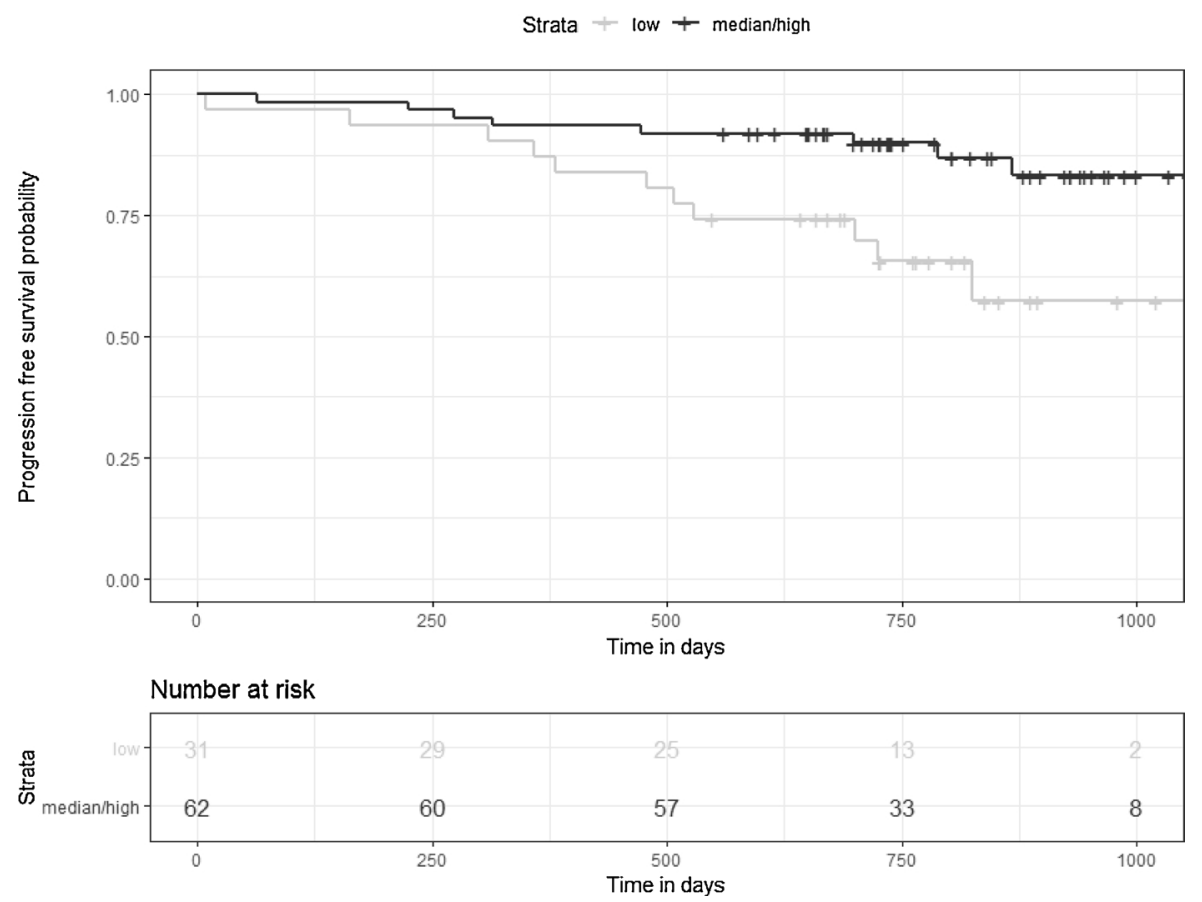

Fig. 1. Overall Survival (upper plot) and Progression Free Survival (lower plot) associated with "medium/high" and "low" L1 VL as measured by ddPCR ( $>5.57$ viral gene copies per cell $=$ medium/high L1 VL).

data provide further proof of the instability of the HPV genome in OPC.

In the adjusted analysis, VL was not independently associated with improved outcomes. This is consistent with the fact that OPC is influenced by various behavioural, demographic and clinical factors and their complex interplay. Consequently, L1 VL may be a proxy of one or a combination of these but nevertheless represents a tool which can be applied objectively to ascertain risk-groups within the HPV positive category. It is also feasible that VL may be used to indicate/inform treatment options. Trials of therapy in OPC based on HPV status have generally relied on qualitative tests; it would be of value to include VL in such studies to determine if it serves as a complimentary biomarker of disease outcomes [33].

There are limitations to the study - although the sample set was well annotated it was still relatively small. In addition, we did not impose 

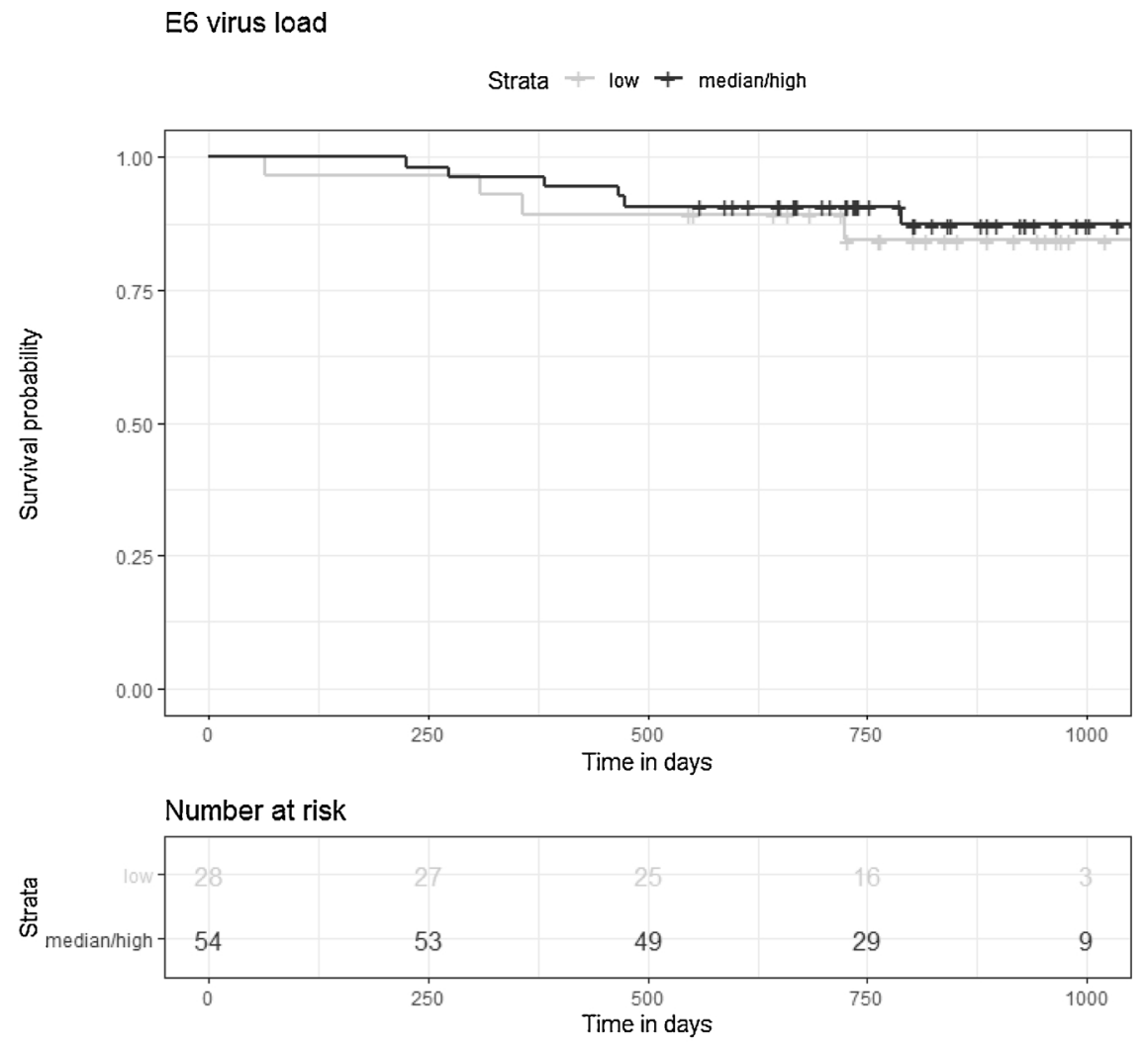

E6 virus load
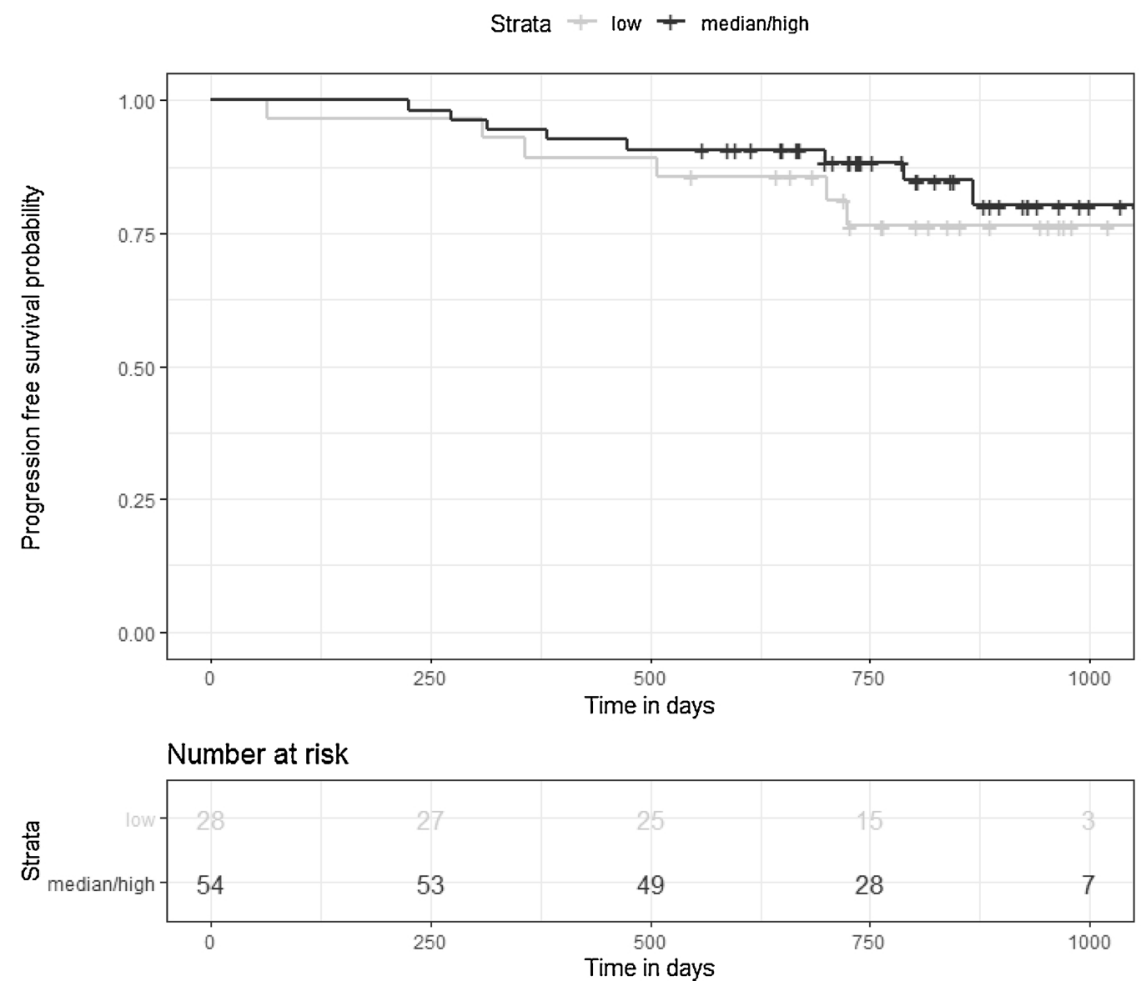

Fig. 2. Overall Survival (upper plot) and Progression Free Survival (lower plot) associated with "medium/high" and "low" E6 VL as measured by ddPCR ( $>8.86$ viral gene copies per cell $=$ medium/high E6 VL).

additional tools to determine viral activity \& physical state which may have helped explain the findings, including the relationship between L1 and E6 ratios. Nevertheless, given the increasing burden of OPC globally and the desire for optimal management strategies - we would argue that assessment of viral load is worthy of further investigation. To this end we aim to confirm our findings in a larger patient cohort where 


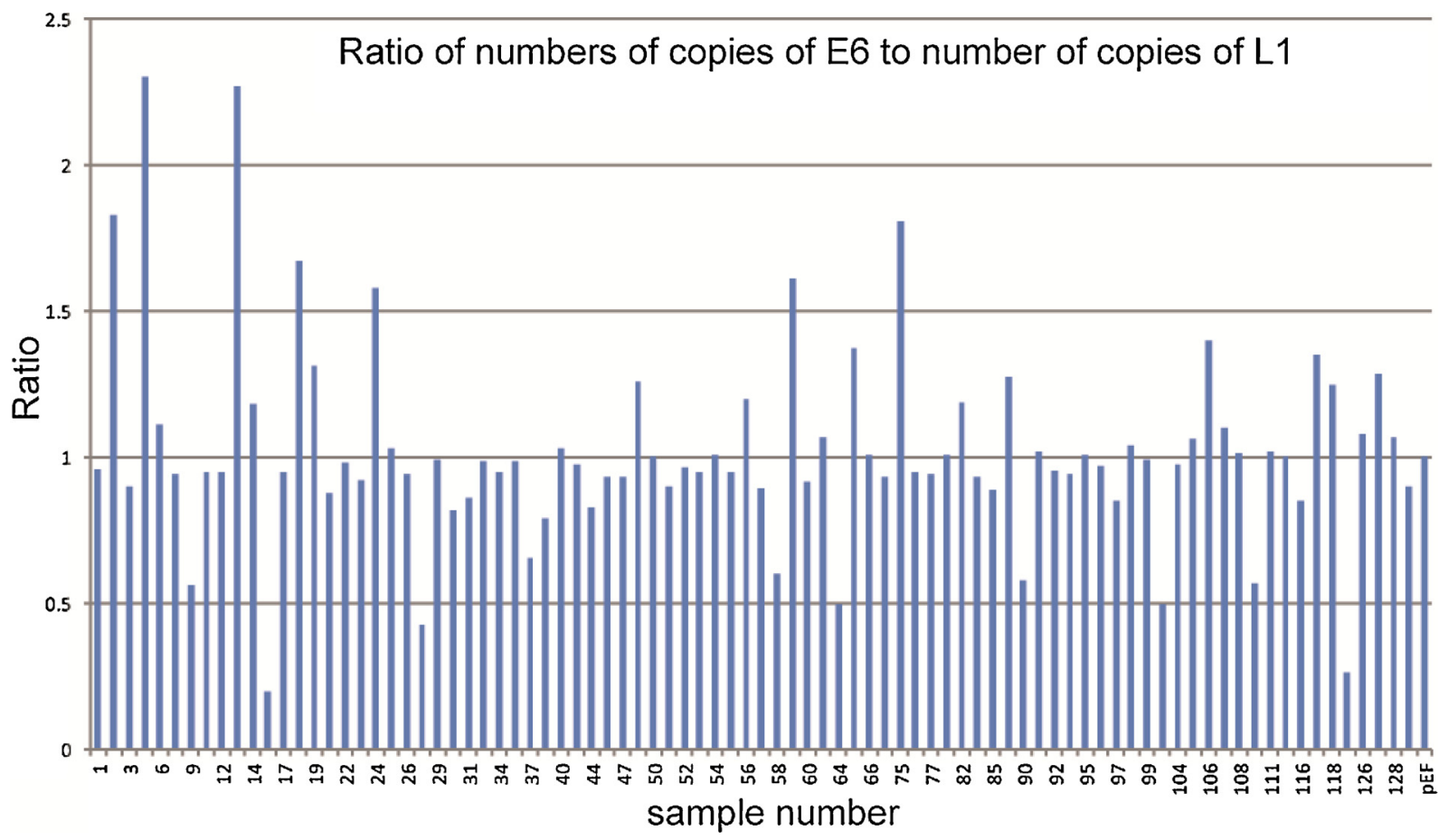

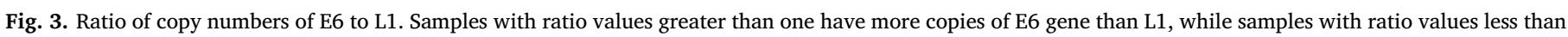
one have more copies of L1 compared to E6 genes.

complimentary biomarkers of viral activity including p16INK4a and E6/E7 mRNA detection [34] are imposed and where increased power would allow further categorisation of load beyond binary groups.

\section{Funding}

K Cuschieri (non-personal) K Cuschieri's institution has received research funding or gratis consumables to support research from the following commercial entities in the last 3 years: Cepheid, Genomica, LifeRiver, Euroimmun, GeneFirst, SelfScreen, Qiagen, Abbott, Hiantis and Hologic.

\section{CRediT authorship contribution statement}

A. Stevenson: Investigation, Methodology, Writing - original draft, Project admnistration. K. Wakeham: Funding acquisition, Data curation, Writing - review \& editing. J. Pan: Formal analysis, Writing original draft. K. Kavanagh: Formal analysis, Writing - review \& editing. D. Millan: Investigation, Methodology, Resources, Project administration. S. Bell: Investigation, Methodology, Resources, Project administration. D. McLellan: Investigation, Methodology, Resources. S.V. Graham: Conceptualization, Writing - original draft, Writing review \& editing, Supervision. K. Cuschieri: Conceptualization, Writing - original draft, Writing - review \& editing, Supervision, Project administration.

\section{Declaration of Competing Interest}

No other authors report a conflict of interest in relation to this work.

\section{Acknowledgments}

We are grateful to staff at the Scottish HPV Reference laboratory for support with sample collation.

\section{Appendix A. Supplementary data}

Supplementary material related to this article can be found, in the online version, at doi:https://doi.org/10.1016/j.jcv.2020.104505.

\section{References}

[1] A.F. Carlander, C. Grønhøj Larsen, D.H. Jensen, E. Garnæs, K. Kiss, L. Andersen, C.H. Olsen, M. Franzmann, E. Høgdall, S.K. Kjær, B. Norrild, L. Specht, E. Andersen, T. van Overeem Hansen, F.C. Nielsen, C. von Buchwald, Continuing rise in oropharyngeal cancer in a high HPV prevalence area: A Danish population-based study from 2011 to 2014, Eur. J. Cancer 70 (2017) 75-82, https://doi.org/10. 1016/j.ejca.2016.10.015 JanuaryEpub 2016 Nov 23.

[2] A.G. Schache, N.G. Powell, K.S. Cuschieri, M. Robinson, S. Leary, H. Mehanna, D. Rapozo, A. Long, H. Cubie, E. Junor, H. Monaghan, K.J. Harrington, C.M. Nutting, U. Schick, A.S. Lau, N. Upile, J. Sheard, K. Brougham, C.M. West, K. Oguejiofor, S. Thomas, A.R. Ness, M. Pring, G.J. Thomas, E.V. King, D.J. McCance, J.A. James, M. Moran, P. Sloan, R.J. Shaw, M. Evans, T.M. Jones, HPV-related oropharynx Cancer in the United Kingdom: an evolution in the understanding of disease etiology, Cancer Res. 15 (November (22)) (2017) 6598-6606, https://doi.org/10.1158/0008-5472.CAN-16-0633 201676.

[3] D. Anantharaman, B. Abedi-Ardekani, D.C. Beachler, T. Gheit, A.F. Olshan, K. Wisniewski, V. Wunsch-Filho, T.N. Toporcov, E.H. Tajara, J.E. Levi, R.A. Moyses, S. Boccia, G. Cadoni, G. Rindi, W. Ahrens, F. Merletti, D.I. Conway, S. Wright, C. Carreira, H. Renard, P. Chopard, S. McKay-Chopin, G. Scelo, M. Tommasino, P. Brennan, G. D'Souza, Geographic heterogeneity in the prevalence of human papillomavirus in head and neck cancer, Int. J. Cancer 1 (9) (2017) 1968-1975, https://doi.org/10.1002/ijc.30608 2017 May140 Epub 2017 Feb 14.

[4] M.L. Gillison, G. D'Souza, W. Westra, E. Sugar, W. Xiao, S. Begum, R. Viscidi, Distinct risk factor profiles for human papillomavirus type 16-positive and human papillomavirus type 16-negative head and neck cancers, J. Natl. Cancer Inst. 19 (March (6)) (2008) 407-420, https://doi.org/10.1093/jnci/djn025 Epub 2008 100Mar 11..

[5] G. D'Souza, D. Anantharaman, T. Gheit, B. Abedi-Ardekani, D.C. Beachler, D.I. Conway, A.F. Olshan, V. Wunsch-Filho, T.N. Toporcov, W. Ahrens, K. Wisniewski, F. Merletti, S. Boccia, E.H. Tajara, J.P. Zevallos, J.E. Levi, M.C. Weissler, S. Wright, G. Scelo, A.L. Mazul, M. Tommasino, P. Brennan, Effect of HPV on head and neck cancer patient survival, by region and tumor site: a comparison of 1362 cases across three continents, Oral Oncol. 62 (2016) 20-27, https:// doi.org/10.1016/j.oraloncology.2016.09.005 NovemberEpub 2016 Sep 26..

[6] B. O'Sullivan, S.H. Huang, et al., Development and validation of a staging system for HPV-related oropharyngeal cancer by the International Collaboration on Oropharyngeal cancer Network for Staging (ICON-S): a multicentre cohort study, Lancet Oncol. (2016), https://doi.org/10.1016/S1470-2045(15)00560-4.

[7] A.M. Chen, C. Felix, P.C. Wang, S. Hsu, V. Basehart, J. Garst, P. Beron, D. Wong, M.H. Rosove, S. Rao, H. Melanson, E. Kim, D. Palmer, L. Qi, K. Kelly, M.L. Steinberg, 
P. Kupelian, M.E. Daly, Reduced-dose radiotherapy for human papillomavirus-associated squamous-cell carcinoma of the oropharynx: a single-arm, phase 2 study, Lancet Oncol. 18 (2017) 803-811.

[8] Andrew P. Stein, Sandeep Saha, Jennifer L. Kraninger, Adam D. Swick, Yu Menggang, Paul F. Lambertg, Randall Kimple, Prevalence of human papillomavirus in oropharyngeal cancer: a systematic review, Cancer J. 21 (3) (2015) 138-1462015.

[9] Zain A. Husain, Tiange Chen, Christopher D. Corso, Zoheng Wang, Henry Park, Benjamin Judson, Wendell Yarbrough, Hari, A comparison of prognostic ability of staging systems for human papillomavirus-Related oropharyngeal squamous cell carcinoma, JAMA Oncology JAMA Oncol. 3 (3) (2017) 358-365, https://doi.org/ 10.1001/jamaoncol.2016.4581.

[10] J.P. Klussmann, S.J. Weissenborn, U. Wieland, V. Dries, J. Kolligs, M. Jungehuelsing, H.E. Eckel, H.P. Dienes, H.J. Pfister, P.G. Fuchs, Prevalence, distribution, and viral load of human papillomavirus 16 DNA in tonsillar carcinomas, Cancer (December(11)) (2001) 2875-2884 PubMed PMID: 117539611;92.

[11] G. Badaracco, A. Venuti, Human papillomavirus therapeutic vaccines in head and neck tumors, Expert Rev. Anticancer Ther. 7 (May(5)) (2007) 753-766 Review. PubMed PMID: 17492938.

[12] Z. Deng, M. Hasegawa, A. Kiyuna, S. Matayoshi, T. Uehara, S. Agena, Y. Yamashita, K. Ogawa, H. Maeda, M. Suzuki, Viral load, physical status, and E6/E7 mRNA expression of human papillomavirus in head and neck squamous cell carcinoma, Head Neck 35 (June(6)) (2013) 800-808, https://doi.org/10.1002/hed.23034 Epub 2012 Jul 13. PubMed PMID: 22791649.

[13] H. Faust, E. Eldenhed Alwan, A. Roslin, J. Wennerberg, O. Forslund, Prevalence of human papillomavirus types, viral load and physical status of HPV16 in head and neck squamous cell carcinoma from the South Swedish Health Care Region, J. Gen. Virol. 97 (November(11)) (2016) 2949-2956, https://doi.org/10.1099/jgv.0. 000611 Epub 2016 Sep 21. PubMed PMID: 27667722.

[14] W.J. Koskinen, R.W. Chen, I. Leivo, A. Mäkitie, L. Bäck, R. Kontio, R. Suuronen, C. Lindqvist, E. Auvinen, A. Molijn, W.G. Quint, A. Vaheri, L.M. Aaltonen, Prevalence and physical status of human papillomavirus in squamous cell carcinomas of the head and neck, Int. J. Cancer 10 (November(3)) (2003) 401-406 PubMed PMID: 14506740107.

[15] T.J. Nulton, A.L. Olex, M. Dozmorov, I.M. Morgan, B. Windle, Analysis of the Cancer genome Atlas sequencing data reveals novel properties of the human Papillomavirus 16 genome in head and neck squamous cell carcinoma, Oncotarget. 14 (March (11)) (2017) 17684-17699, https://doi.org/10.18632/oncotarget. 151798 PubMed PMID: 28187443;PubMed Central PMCID: PMC5392278.

[16] N.V. Anayannis, N.F. Schlecht, M. Ben-Dayan, R.V. Smith, T.J. Belbin, T.J. Ow, D.M. Blakaj, R.D. Burk, S.M. Leonard, C.B. Woodman, J.L. Parish, M.B. Prystowsky, Association of an intact E2 gene with higher HPV viral load, higher viral oncogene expression, and improved clinical outcome in HPV16 positive head and neck squamous cell carcinoma, PLoS One 16 (Febuary(2)) (2018) e0191581, , https:// doi.org/10.1371/journal.pone.0191581 eCollection 2018.13 PubMed PMID: 29451891; PubMed Central PMCID: PMC5815588.

[17] D. Holzinger, M. Schmitt, G. Dyckhoff, A. Benner, M. Pawlita, F.X. Bosch, Viral RNA patterns and high viral load reliably define oropharynx carcinomas with active HPV16 involvement, Cancer Res. 1 (October (19)) (2012) 4993-5003, https://doi. org/10.1158/0008-5472.CAN-11-3934 72 Epub 2012 Sep 18. PubMed PMID: 22991302.

[18] K. Wakeham, K. Kavanagh, K. Cuschieri, D. Millan, K.G. Pollock, S. Bell, K. Burton, N.S. Reed, S.V. Graham, HPV status and favourable outcome in vulvar squamous cancer, Int. J. Cancer 1 (March(5)) (2017) 1134-1146, https://doi.org/10.1002/ijc. 30523.PubMed PMID: 27864932140.

[19] K. Cuschieri, D.H. Brewster, C. Graham, S. Nicoll, A.R. Williams, G.I. Murray, D. Millan, I. Johannessen, A. Hardie, H.A. Cubie, Influence of HPV type on prognosis in patients diagnosed with invasive cervical cancer, Int. J. Cancer 1 (December (11)) (2014) 2721-2726, https://doi.org/10.1002/ijc.28902 135 Epub 2014 Apr 29. PubMed PMID: 24740764.

[20] D. Yurick, G. Khoury, B. Clemens, L. Loh, H. Pham, K. Kedzierska, L. Einsiedel, D. Purcell, Multiplex droplet digital PCR assay for quantification of human T-Cell leukemia virus type 1 subtype c DNA proviral load and t cells from blood and respiratory exudates sampled in a remote setting, J. Clin. Microbiol. 30 (January (2) 2019), https://doi.org/10.1128/JCM.01063-18 57 Print 2019 Feb.). pii: e0106318. PubMed PMID: 30518541; PubMed Central PMCID: PMC6355533.
[21] Y. Zhang, Z. Zhang, Z. Wang, Z. Wang, C. Wang, C. Feng, W. Yuan, X. Lin, S. Wu, Development of a droplet digital PCR assay for sensitive detection of porcine circovirus 3, Mol. Cell. Probes 43 (2019) 50-57, https://doi.org/10.1016/j.mcp. 2018. 11.005 FebuaryEpub 2018 Nov 20. PubMed PMID: 30468765.

[22] R. Okada, T. Ito, F. Nomura, S. Kirimura, Y. Cho, M. Sekine, Y. Tateishi, Y. Ariizumi, T. Asakage, The quantitative analysis of the human papillomavirus DNA load in submandibular gland lesions with droplet digital polymerase chain reaction, Acta Otolaryngol. 139 (January(1)) (2019) 105-110, https://doi.org/10.1080/ 00016489.2018.1562215 Epub 2019 Feb 2. PubMed PMID: 30714463.

[23] K. Wakeham, J. Pan, K.G. Pollock, D. Millan, S. Bell, D. McLellan, A. McPhaden, D.I. Conway, S.V. Graham, K. Kavanagh, K. Cuschieri, A prospective cohort study of Human Papillomavirus driven oropharyngeal cancers: implications for prognosis and immunisation, Clin. Oncol. R. Coll. Radiol. (R Coll Radiol) 31 (9) (2019) Septembere132-e142.

[24] S.A. Bustin, V. Benes, J.A. Garson, J. Hellemans, J. Huggett, M. Kubista, R. Mueller, T. Nolan, M.W. Pfaffl, G.L. Shipley, J. Vandesompele, C.T. Wittwer, The MIQE guidelines: minimum information for publication of quantitative real-time PCR experiments, Clin. Chem. 55 (April(4)) (2009) 611-622, https://doi.org/10.1373/ clinchem.2008.112797 Epub 2009 Feb 26.

[25] J.F. Huggett, C.A. Foy, V. Benes, K. Emslie, J.A. Garson, R. Haynes, J. Hellemans, M. Kubista, R.D. Mueller, T. Nolan, M.W. Pfaffl, G.L. Shipley, J. Vandesompele, C.T. Wittwer, S.A. Bustin, The digital MIQE guidelines: minimum information for publication of quantitative digital PCR experiments, Clin. Chem. 59 (June(6)) (2013) 892-902, https://doi.org/10.1373/clinchem.2013.206375 Epub 2013 Apr 9

[26] G. Chambers, D. Millan, K. Cuschieri, H.A. Cubie, S.V. Graham, Assessing the detection of human papillomavirus late mRNA in liquid base cytology samples for risk stratification of cervical disease, J. Med. Virol. 86 (April(4)) (2014) 627-633, https://doi.org/10.1002/jmv.23793 Epub 2013 Oct 19.

[27] M. McFarlane, A.I. MacDonald, A. Stevenson, Graham SV human papillomavirus 16 oncoprotein expression is controlled by the cellular splicing factor SRSF2 (SC35), J. Virol. 89 (May(10)) (2015) 5276-5287, https://doi.org/10.1128/JVI.03434-14 Epub 2015 Feb 25.

[28] V.L. Biron, M. Kostiuk, A. Isaac, L. Puttagunta, D.A. O'Connell, J. Harris, D.W. Côté, H. Seikaly, Detection of human papillomavirus type 16 in oropharyngeal squamous cell carcinoma using droplet digital polymerase chain reaction, Cancer. 15 (May (10)) (2016) 1544-1551, https://doi.org/10.1002/cncr.29976 Epub 2016 Mar 17. 122 PubMed PMID: 26989832

[29] A. Antonsson, L. Knight, B.J. Panizza, S.V. Porceddu, S. Emmett, D.C. Whiteman, HPV-16 viral load in oropharyngeal squamous cell carcinoma using digital PCR, Acta Otolaryngol. 138 (September(9)) (2018) 843-847, https://doi.org/10.1080/ 00016489.2018.1461239 Epub 9. PubMed PMID: 29741428

[30] E.S. Prigge, M. Arbyn, M. von Knebel Doeberitz, M. Reuschenbach, Diagnostic accuracy of p16(INK4a) immunohistochemistry in oropharyngeal squamous cell carcinomas: a systematic review and meta-analysis, Int. J. Cancer 1 (March (5)) (2017) 1186-1198, https://doi.org/10.1002/ijc.30516 Epub 2016 Dec 2. Review. PubMed PMID: 27859245140.

[31] I.M. Morgan, L.J. DiNardo, B. Windle, Integration of Human Papillomavirus Genomes in Head and Neck Cancer: Is It Time to Consider a Paradigm Shift? Viruses. 3 (August (8)) (2017), https://doi.org/10.3390/v9080208 pii: E208. Review.9 PubMed PMID: 28771189;PubMed Central PMCID: PMC5580465.

[32] K. Akagi, J. Li, T.R. Broutian, H. Padilla-Nash, W. Xiao, B. Jiang, J.W. Rocco, T.N. Teknos, B. Kumar, D. Wangsa, D. He, T. Ried, D.E. Symer, M.L. Gillison, Genome-wide analysis of HPV integration in human cancers reveals recurrent, focal genomic instability, Genome Res. 24 (Febuary(2)) (2014) 185-199, https://doi. org/10.1101/gr.164806.113 Epub 2013 Nov 7.PubMed PMID: 24201445; PubMed Central PMCID: PMC3912410.

[33] C. Ndiaye, M. Mena, L. Alemany, M. Arbyn, X. Castellsagué, L. Laporte, F.X. Bosch, S. de Sanjosé, H. Trottier, HPV DNA, E6/E7 mRNA, and p16INK4a detection in head and neck cancers: a systematic review and meta-analysis, Lancet Oncol. 15 (November(12)) (2014) 1319-1331, https://doi.org/10.1016/S1470-2045(14) 70471-1 Epub 2014 Oct 16. Erratum in: Lancet Oncol. 2015 Jun;16(6):e262.

[34] K.Y. Kim, J.S. Lewis, Z. Chen, J Current status of clinical testing for human papillomavirus in oropharyngeal squamous cell carcinoma, Pathol Clin Res. 4 (October(4)) (2018) 213-226 Published online 2018 Sep 18. doi: 10.1002/cjp2.111 PMCID: PMC6174616. 